\title{
Effects of Biostimulants on Primary and Secondary Substance Contents in Lettuce Plants
}

\author{
Se Ji Jang and Yong In Kuk *
}

check for

updates

Citation: Jang, S.J.; Kuk, Y.I. Effects

of Biostimulants on Primary and Secondary Substance Contents in Lettuce Plants. Sustainability 2021, 13, 2441. https://doi.org/10.3390/ su13052441

Academic Editor: Emanuele Radicetti

Received: 28 January 2021

Accepted: 19 February 2021

Published: 24 February 2021

Publisher's Note: MDPI stays neutral with regard to jurisdictional claims in published maps and institutional affiliations.

Copyright: (c) 2021 by the authors. Licensee MDPI, Basel, Switzerland. This article is an open access article distributed under the terms and conditions of the Creative Commons Attribution (CC BY) license (https:/ / creativecommons.org/licenses/by/ $4.0 /)$.
Department of Oriental Medicine Resources, Sunchon National University, Suncheon 57922, Korea; sejijang@daum.net

* Correspondence: yikuk@sunchon.ac.kr

\begin{abstract}
Lettuce (Lactuca sativa L.) is not only easy to grow, but it is also common in diets around the world. This study was conducted to determine the impact of Chinese chive (Allium tuberosum Rottler), soybean (Glycine max L.) leaf, and soybean stem extracts on lettuce plants' secondary substances, minerals, amino acids, and free sugars. This study was carried out in order to better understand which types of plant extract applications are most effective in increasing lettuce plants' nutritional value. While not all applications produced an increased nutritional value in the lettuce plants, we found that soybean leaf extract treatments increased the $\mathrm{Mg}$ and Ca contents and Chinese chive treatments increased the Fe contents in the lettuce plants. Additionally, glucose and maltose contents in lettuce plants were higher after treatments of Chinese chive and soybean leaf extracts. Finally, all selected extracts increased the total and free amino acid levels in our test plants.
\end{abstract}

Keywords: agricultural material; biostimulant; crop quality; lettuce; plant extract; plant nutrition

\section{Introduction}

While the benefits are apparent, the mechanisms underlying biostimulants are not well understood. However, what is known is that certain plant extracts are rich sources of macroand micro-elemental nutrients, amino acids, and other compounds that may enhance the nutritional value of plants that have been treated with these extracts. While there have been several studies on biostimulants [1-3], to the best of our knowledge, no studies have yet investigated the chemical components of lettuce (Lactuca sativa L.) treated with Chinese chive (Allium tuberosum Rottler) or soybean (Glycine max L.) stem and leaf extracts.

Our studies were conducted in order to better understand how extract applications can potentially increase nutritional values in one of the world's most commonly grown plants, lettuce. The methods of biostimulation in this study are forms of environmentally friendly, sustainable agriculture which reduce the use of chemical inputs such as pesticides and fertilizers [4].

One of the major goals of agricultural production is to improve value-added traits, especially nutritional factors $[5,6]$. Because improved crop nutrition has a direct effect on consumers' health, methods such as biofortification have become increasingly common in the pursuit of increased nutrition in crops [7,8]. However, due to the inherit complexities of biofortification, it is beneficial to examine other, less complicated means of increasing crop nutrition. Thus, the focus of this study was to evaluate the effectiveness of plant extract applications in increasing crop quality and nutritional value.

Soybean is one of the most commonly consumed legumes worldwide, with 200 million metric tons produced each year [9]. In Korea, the area of soybean cultivation is increasing, with 8129 ha being used for its growth in 2016 [10]. At harvest time, there are many fallen soybean leaves and stems; however, these products are usually not used for commercial purposes and are often discarded. As this study will show, this plant by-product may have significant potential to improve crop nutrition. 
Chinese chive, a member of the same family as onion and garlic, is a perennial plant with thin leaves that grows to a height of about $40 \mathrm{~cm}$ [11]. This plant can be continually harvested seven to eight times per years for 5-6 years with one sowing. Recently, the area used for cultivation of Chinese chive, as well as its utilization as a vegetable, have been increasing [12].

Lettuce, which is a member of the Compositae family, is a major vegetable used throughout the world and can be grown virtually anywhere [13]. In Korea, lettuce is commonly used as a "wrap vegetable", for various dishes and is eaten along with perilla (Perilla frutescens) and pakchoi (Brassica rapa L. var. chinensis) [14].

In previous studies [15], we determined that Chinese chive and soybean leaves and stems were effective biostimulants for crop promotion. In the case of Chinese chive, this plant is extremely prolific after a single planting. In the case of soybean, this plant can be grown almost anywhere [9]. As such, these two plants were ideal candidates for our study. Extracts such as these contain a wide range of bioactive compounds that are still mostly unknown. These products are usually able to improve nutrient use efficiency, stimulating plant development and allowing reduced fertilizer consumption [3]. For example, nutritional qualities such as carbohydrates, proteins, and mineral contents of wheat grains were improved after spray treatment of plants with $0.25,0.50$, and $1.0 \%$ K. alvarezii seaweed [16]. Thus, this study was conducted to determine if the levels of secondary substances, minerals, amino acids, and free sugars could be increased in lettuce plants by Chinese chive and soybean leaf and stem extract treatments.

\section{Materials and Methods}

\subsection{Plant Materials and Treatments}

In a previous study published in 2017, we examined extracts made from 38 different agro-materials commonly used in traditional Korean agriculture with the purpose of determining which materials and extraction methods could be combined to produce the most effective growth-promoting extracts [15]. From this study, we determined that among the most effective extracts were those made using a water extraction method of Chinese chive (cv. Sanbuchu), soybean leaf (cv. Daewon), and soybean stem (cv. Daewon). Thus, these extracts were used for further examination in this study.

Lettuce (cv. Cheonghacheongchima) seeds were sown in pots $(200 \mathrm{~mL})$ filled with potting soil (Hungnong-Bio Soil, Suncheon, South Korea) in a greenhouse under light conditions of $14 \mathrm{~h}$ light $/ 10 \mathrm{~h}$ dark. Day temperatures were $30 \pm 2{ }^{\circ} \mathrm{C}$ and night temperatures were $20 \pm 3{ }^{\circ} \mathrm{C}$ with $70 \%$ relative humidity and $500 \mu \mathrm{mol} \mathrm{m}^{-2} \mathrm{~s}^{-1}$ PAR. At the $4-5$ leaf stages for lettuce, the seedlings were treated by foliar spray with an aqueous solution $(5 \mathrm{~mL}$ per pot) of the aforementioned extracts at a $5 \%$ concentration.

The above treated leaves were determined 1,2, and 7 days after treatments with Chinese chive and soybean extracts: Total phenol contents, total flavonoid contents, DPPH radical scavenging activity, mineral compositions, total amino acids, free amino acids, and free sugar contents. In addition, the aforementioned parameters were measured in Chinese chive and soybean leaf and stems themselves.

\subsection{Total Phenol and Flavonoid Contents and DPPH Scavenging Activity}

Total phenol and flavonoid contents and scavenging activity were analyzed after $0.5 \mathrm{~g}$ of the dried plant samples were mixed with $10 \mathrm{~mL}$ of $99.9 \%$ ethanol in a mortar, ground in a grinder, and centrifuged at $5000 \mathrm{rpm}$ for $10 \mathrm{~min}$.

To determine total phenolic contents, $1 \mathrm{~mL}$ of extract was added to $3 \mathrm{~mL}$ of distilled water and $1 \mathrm{~mL}$ of Folin-Denis' reagent, and then shaken for $5 \mathrm{~min}$. The mixed solution was left for $1 \mathrm{~h}$ at room temperature and measured using a UV spectrophotometer at $640 \mathrm{~nm}$ (UV-1601; Shimadzu Co., Kyoto, Japan). 
For measuring total flavonoid contents, $0.5 \mathrm{~mL}$ of extract were mixed with $1.5 \mathrm{~mL}$ of ethanol (95\%), $10 \%$ of $\mathrm{AlCl}_{3}, 1 \mathrm{M}$ of potassium acetate, and $2.8 \mathrm{~mL}$ of distilled water. The mixed solution was then left for $40 \mathrm{~min}$ at room temperature and measured using a UV spectrophotometer at $415 \mathrm{~nm}$ (UV-1601; Shimadzu Co., Kyoto, Japan).

To measure the DPPH scavenging activity, the $100 \mu \mathrm{L}$ of extract, $500 \mu \mathrm{L}$ of $0.1 \mathrm{M}$ acetate buffer solution ( $\mathrm{pH} 5.5), 250 \mu \mathrm{L}$ of $0.5 \mathrm{mM}$ DPPH (2,2-diphenyl-1-picrylhydarzyl), and $400 \mu \mathrm{L}$ of ethanol were mixed for $30 \mathrm{~min}$ at room temperature. The mixed solution was measured using a UV spectrophotometer at 517 nm (UV-1601; Shimadzu Co., Kyoto, Japan).

\subsection{Mineral Analyses}

Leaves were put in a dry oven at $40{ }^{\circ} \mathrm{C}$ for three days and ground using a leaf grinder to analyze mineral nutrient contents [17]. Two grams of the ground samples were diluted with $10 \mathrm{~mL}$ of nitric acid $(20 \%, v / v)$, slowly raising the temperature on a heat plate until the solution was clear. The solution was mixed up $50 \mathrm{~mL}$ by distilled water and allowed to pass through a Whatman No. 6 filter paper, which was then measured by an inductively coupled plasma atomic emission spectrometer (ICP; Optima 3300 DV ICP; PerkinElmer Co., Waltham, MA, USA).

\subsection{Total Amino Acid, Free Amino Acid, and Free Sugar Analyses}

Two grams of the dried plant samples were put in a heat-resisting vial, and hydrolyzed with $15 \mathrm{~mL}$ of $6 \mathrm{~N} \mathrm{HCl}$ in a dry oven at $110{ }^{\circ} \mathrm{C}$ for $24 \mathrm{~h}$. They were then centrifuged at $15,000 \mathrm{rpm}$ for $30 \mathrm{~min}$ and cooled down at room temperature to measure total amino acids [18]. In order to remove hydrochloric acid and water from the solution, it was allowed to evaporate at $50{ }^{\circ} \mathrm{C}$. We then added $10 \mathrm{~mL}$ of $\mathrm{pH} 2.2$ sodium citrate buffer solution and this mixture was allowed to pass through a $0.22 \mu \mathrm{m}$ membrane filter. The filtrate was analyzed by a S433 amino acid analyzer (Sykam Co., Eresing, Germany).

Ten grams of the dried plant samples were homogenized using an Ace Homogenizer (Nissei Co., Tokyo, Japan) to extract free sugar and filtrated using a $0.45 \mu \mathrm{m}$ membrane filter to measure free amino acids [18]. We then added $25 \mathrm{mg}$ of sulfosalicylic acid to $10 \mathrm{~mL}$ of the filtrate. This mixture was kept in a room at $4{ }^{\circ} \mathrm{C}$ for $4 \mathrm{~h}$ and then centrifuged at $15,000 \mathrm{rpm}$ for $30 \mathrm{~min}$, and the supernatant was filtrated using a $0.22 \mu \mathrm{m}$ membrane filter. The filtrate was analyzed by an S433 amino acid analyzer (Sykam Co., Eresing, Germany).

Fructose, glucose, and sucrose contents in plants were analyzed according to the method of Wilson et al. [19]. The $5 \mathrm{~g}$ of dried plant samples were added to $50 \mathrm{~mL}$ of distilled water and shaken in a $30{ }^{\circ} \mathrm{C}$ water bath for $30 \mathrm{~min}$. This was then centrifuged at 15,000 rpm for $30 \mathrm{~min}$ and filtrated using a $0.45 \mu \mathrm{m}$ membrane filter. From this filtrate, $20 \mu \mathrm{L}$ were used to analyze the free sugar contents using high-performance liquid chromatography (HPLC, Spectra-Physics P4000, Fremont, CA, USA).

\subsection{Statistical Analysis}

All experiments were carried out with 3 replications. Significant differences were determined using analysis of variance (ANOVA). Analyses were performed using Statistical Analysis Systems software [20]. In the case of significant differences, means were separated by Duncan's multiple range test at $P \leq 0.05$.

\section{Results and Discussion}

\subsection{Extract Treatments' Effects on Lettuce Plants' Total Phenol and Flavonoid Contents and DPPH Radical Scavenging Activity}

Initially, total phenol and flavonoid contents and DPPH radical scavenging activity were measured in Chinese chive and soybean leaves and stems themselves. The total phenol contents of the three materials ranged from 3.47 to $1.93 \mathrm{mg} / \mathrm{g}$ DW in the order Chinese chive $>$ soybean leaf $>$ soybean stem (Table 1 ). Furthermore, the total flavonoid contents in Chinese chive were 4.3 times higher than in soybean leaf. However, DPPH radical scavenging activities did not differ significantly between Chinese chives and soybean 
leaves. Moreover, the total flavonoid contents and DPPH radical scavenging activities in soybean stems were very low. In another study, soybean leaves were shown to contain higher levels of isoflavones [21]. Furthermore, phenolic acids and flavonoids such as salicylic, 4-hydroxybenzoic, valillic, 4-hydrooxycinnamic, ferulic, caffeic, gentisic, and quercetin in soybean leaf extracts were detected upon HPLC analysis [22]. There is also a large amount of glycine, serine, alanine, and histidine, as well as substances related to antioxidant activity, in soybean leaf extracts [23]. Chinese chives are also known to contain relatively higher contents of chlorophyll, $\beta$-carotene, vitamin $C$, sulfur-containing compounds, and many kinds of flavonoids [12]. Taking all of this into consideration, secondary metabolites such as flavonoid contents could be increased in lettuce plants if they were treated with extracts from Chinese chive and soybean leaf and stems.

Table 1. Total phenols, total flavonoids and DPPH radical scavenging activity in Chinese chive leaf and soybean leaf and stems.

\begin{tabular}{cccc}
\hline Material (Dry) & Total Phenol Content (mg/g DW. $\left.{ }^{\mathrm{z}}\right)$ & $\begin{array}{c}\text { Total Flavonoid Content } \\
(\mu \mathrm{g} / \mathrm{g} \text { DW.) }\end{array}$ & $\begin{array}{c}\text { DPPH Free Scavenging } \\
\text { Activity (\%) }\end{array}$ \\
\hline Chinese chive & $3.47^{\mathrm{a} *}$ & $90.0^{\mathrm{a}}$ & $33.3^{\mathrm{a}}$ \\
Soybean leaf & $1.93^{\mathrm{b}}$ & $21.0^{\mathrm{b}}$ & $28.1^{\mathrm{ab}}$ \\
Soybean stem & $0.59^{\mathrm{c}}$ & $1.2^{\mathrm{c}}$ & $9.3^{\mathrm{b}}$ \\
\hline
\end{tabular}

DW-dry weight. * Means within a column followed by the same letters are not significantly different at $5 \%$ level according to Duncan's multiple range test.

The total phenol and flavonoid contents and DPPH scavenging activity of the fourth and first leaves of lettuce were determined 1,2, and 7 days after Chinese chive and soybean leaf and stem treatments (Table 2). The total phenol contents in lettuce plants showed no significant differences among treatments when compared with the control, regardless of plant parts (fourth and first leaves) and time after treatment. However, a notable exception would be in fourth lettuce leaves observed 1 day after treatment with Chinese chive extract. In this particular scenario, we found that the total phenol contents were significantly higher. Seeing as this was the exception and not the rule, we concluded that the extracts used in this study do not increase total phenol contents.

However, fertilization of rocket (Eruca vesicaria subsp. sativa) plants with $2 \%$ leaf and $3 \%$ twig extracts of Moringa oleifera increased phenol contents [2]. Similar to the total phenol contents, total flavonoid contents and DPPH radical scavenging activities showed generally no significant differences after treatments with Chinese chive, soybean leaf, and soybean stem extracts when compared with the control, regardless of plant parts (young and old leaves) and time after treatment. However, the total flavonoid contents of the first leaves of lettuce were significantly higher in plants treated with Chinese chive and soybean stem extracts than the control at only 7 days after treatment. Although total phenol and flavonoid contents in Chinese chives were higher than in soybean leaves and stems (Table 1), these increased levels may not be related to an increase in their contents in lettuce plants after treatment with Chinese chive and soybean leaf and stem extracts. Unlike in the present study, application of $1.0 \mathrm{~g} / \mathrm{L}$ extract of Ascophyllum nodosum increased the total phenol and flavonoid contents of treated spinach leaves [24]. 
Table 2. Changes in total phenols, total flavonoids and DPPH radical scavenging activity of lettuce plants after treatments of selected plant extracts.

\begin{tabular}{|c|c|c|c|c|c|}
\hline $\begin{array}{l}\text { Sampling Day } \\
\text { (DAT) }\end{array}$ & Harvest Part & Water Extract $(5 \%)$ & $\begin{array}{c}\text { Total Phenol } \\
\text { Content (mg/g FW.) }\end{array}$ & $\begin{array}{c}\text { Total Flavonoid } \\
\text { Content ( } \mu \text { g/g FW.) }\end{array}$ & $\begin{array}{c}\text { DPPH Free Scavenging } \\
\text { Activity (\%) }\end{array}$ \\
\hline \multirow{8}{*}{1} & \multirow{4}{*}{ Fourth leaf } & Control & $0.47^{\mathrm{b} *}$ & $0.056^{\mathrm{a}}$ & $26.91^{a}$ \\
\hline & & $\mathrm{CC}$ & $0.86^{\mathrm{a}}$ & $0.054^{\mathrm{a}}$ & $31.78^{a}$ \\
\hline & & SL & $0.64^{\mathrm{b}}$ & $0.05^{\mathrm{a}}$ & $23.69^{a}$ \\
\hline & & SS & $0.69^{a b}$ & $0.053^{a}$ & $29.6^{a}$ \\
\hline & \multirow{4}{*}{ First leaf } & Control & $0.76^{\mathrm{a}}$ & $0.058^{\mathrm{a}}$ & $34.85^{\mathrm{a}}$ \\
\hline & & $\mathrm{CC}$ & $0.85^{\mathrm{a}}$ & $0.059^{a}$ & $36.94^{\mathrm{a}}$ \\
\hline & & SL & $0.90^{\mathrm{a}}$ & $0.054^{a}$ & $32.8^{\mathrm{a}}$ \\
\hline & & SS & $0.79^{a}$ & $0.054^{\mathrm{a}}$ & $37.95^{\mathrm{a}}$ \\
\hline \multirow{8}{*}{2} & \multirow{4}{*}{ Fourth leaf } & Control & $0.68^{a}$ & $0.045^{\mathrm{a}}$ & $25.30^{\mathrm{a}}$ \\
\hline & & $\mathrm{CC}$ & $0.75^{\mathrm{a}}$ & $0.052^{a}$ & $27.32^{\mathrm{a}}$ \\
\hline & & SL & $0.53^{a}$ & $0.042^{\mathrm{a}}$ & $21.62^{\mathrm{a}}$ \\
\hline & & SS & $0.70^{a}$ & $0.052^{a}$ & $26.91^{\mathrm{a}}$ \\
\hline & \multirow{4}{*}{ First leaf } & Control & $0.74^{\mathrm{ab}}$ & $0.046^{\mathrm{a}}$ & $37.35^{\mathrm{a}}$ \\
\hline & & $\mathrm{CC}$ & $0.76^{\mathrm{a}}$ & $0.053^{a}$ & $34.04^{\mathrm{a}}$ \\
\hline & & SL & $0.50^{b}$ & $0.042^{\mathrm{a}}$ & $27.23^{a}$ \\
\hline & & SS & $0.74^{a b}$ & $0.046^{\mathrm{a}}$ & $33.9^{a}$ \\
\hline \multirow{8}{*}{7} & \multirow{4}{*}{ Fourth leaf } & Control & $0.54^{\mathrm{a}}$ & $0.076^{\mathrm{a}}$ & $37.5^{\mathrm{a}}$ \\
\hline & & $\mathrm{CC}$ & $0.59^{a}$ & $0.077^{\mathrm{a}}$ & $38.9^{a}$ \\
\hline & & SL & $0.54^{\mathrm{a}}$ & $0.086^{a}$ & $39.0^{a}$ \\
\hline & & SS & $0.56^{\mathrm{a}}$ & $0.085^{a}$ & $39.0^{\mathrm{a}}$ \\
\hline & \multirow{4}{*}{ First leaf } & Control & $0.48^{a}$ & $0.060^{b}$ & $36.1^{a}$ \\
\hline & & CC & $0.48^{\mathrm{a}}$ & $0.077^{\mathrm{a}}$ & $36.1^{\mathrm{a}}$ \\
\hline & & SL & $0.56^{\mathrm{a}}$ & $0.069^{a b}$ & $38.9^{a}$ \\
\hline & & SS & $0.47^{\mathrm{a}}$ & $0.076^{\mathrm{a}}$ & $37.8^{a}$ \\
\hline
\end{tabular}

DAT_-day after treatment, FW—fresh weight, CC—Chinese chive, SL—soybean leaf, S—soybean stem. * Means within a column followed by the same letters are not significantly different at $5 \%$ level according to Duncan's multiple range test.

\subsection{Extract Treatments' Effects on Lettuce Plants' Mineral Content}

The concentrations of $\mathrm{K}, \mathrm{Mn}$, and $\mathrm{P}$ in Chinese chives were significantly higher than in soybean leaves and stems (Table 3). Additionally, $\mathrm{Ca}$ and Fe contents in soybean leaves were 4.6-5.7 and 2-64 times higher than in Chinese chives and soybean stems, respectively. However, mineral contents in soybean stems were generally lower than in Chinese chive and soybean leaves. After soybean leaf extract treatments were applied to lettuce plants, the $\mathrm{Mg}$ and Ca contents in the lettuce plants increased (Table 4), while the Fe content in the lettuce plants increased after Chinese chive extract treatments. Other mineral contents in lettuce plants were not negatively affected by treatment with Chinese chive and soybean leaf and stem extracts.

Table 3. Mineral contents in Chinese chive leaf, soybean leaf, and soybean stems (unit: ppm).

\begin{tabular}{cccc}
\hline Element & Chinese Chive & Soybean Leaf & Soybean Stem \\
\hline $\mathrm{Mg}$ & $727.33^{\mathrm{a}}$ & $767.33^{\mathrm{a}}$ & $406.15^{\mathrm{b}}$ \\
$\mathrm{Ca}$ & $1729.00^{\mathrm{b}}$ & $8025.00^{\mathrm{a}}$ & $1395.67^{\mathrm{b}}$ \\
$\mathrm{Na}$ & $220.78^{\mathrm{a}}$ & $156.53^{\mathrm{b}}$ & $180.70^{\mathrm{ab}}$ \\
$\mathrm{K}$ & $11,395.00^{\mathrm{a}}$ & $981.17^{\mathrm{c}}$ & $2937.83^{\mathrm{b}}$ \\
$\mathrm{Zn}$ & $0.00^{\mathrm{a}}$ & 0.00 & 0.00 \\
$\mathrm{Cu}$ & $1.65^{\mathrm{a}}$ & $1.98^{\mathrm{a}}$ & $1.50^{\mathrm{a}}$ \\
$\mathrm{Fe}$ & $32.98^{\mathrm{b}}$ & $64.20^{\mathrm{a}}$ & $0.00^{\mathrm{c}}$ \\
$\mathrm{Mn}$ & $57.22^{\mathrm{a}}$ & $44.83^{\mathrm{b}}$ & $0.00^{\mathrm{c}}$ \\
$\mathrm{P}$ & $8.33^{\mathrm{a}}$ & $0.00^{\mathrm{b}}$ & $0.00^{\mathrm{b}}$
\end{tabular}

${ }^{*}$ Means within a row followed by the same letters are not significantly different at $5 \%$ level according to Duncan's multiple range test.

There are several similar studies which have shown that the mineral content in plants can be increased by plant extract applications. For example, applications of biochar at $2 \%$ 
and seaweed extract at $1 \mathrm{~g} / \mathrm{L}$ caused a significant increase in $\mathrm{Cu}, \mathrm{Mn}$, and $\mathrm{Zn}$ contents in wheat plants when compared with the control [25]. Moreover, the N, P, K, Ca, Mg, and Fe contents in rocket plants increased after being treated with a Moringa oleifera extract made from $2 \%$ leaf and 3\% twig concentrations [2]. Additionally, applications of seaweed extract have been shown to increase the leaf accumulation of $\mathrm{N}, \mathrm{P}, \mathrm{K}, \mathrm{Mg}$, and $\mathrm{Zn}$ in grapevines [26].

Table 4. Changes in mineral contents of lettuce plants after treatments of selected plant extracts. Parameters were measured at 7 days after treatment (unit: ppm).

\begin{tabular}{ccccc}
\hline Element & Control & Chinese Chive & Soybean Leaf & Soybean Stem \\
\hline $\mathrm{Mg}$ & $574.52^{\mathrm{b} *}$ & $612.93^{\mathrm{ab}}$ & $652.76^{\mathrm{a}}$ & $590.61^{\mathrm{ab}}$ \\
$\mathrm{Na}$ & $2475.24^{\mathrm{a}}$ & $2704.41^{\mathrm{a}}$ & $2575.49^{\mathrm{a}}$ & $2533.45^{\mathrm{a}}$ \\
$\mathrm{K}$ & $25,022.78^{\mathrm{a}}$ & $26,408.82^{\mathrm{a}}$ & $24,465.18^{\mathrm{a}}$ & $24,600.39^{\mathrm{a}}$ \\
$\mathrm{Ca}$ & $1311.35^{\mathrm{b}}$ & $1396.10^{\mathrm{b}}$ & $1545.77^{\mathrm{a}}$ & $1311.54^{\mathrm{b}}$ \\
$\mathrm{Fe}$ & $47.29^{\mathrm{b}}$ & $58.77^{\mathrm{a}}$ & $51.13^{\mathrm{ab}}$ & $44.10^{\mathrm{b}}$ \\
$\mathrm{Mn}$ & $26.65^{\mathrm{a}}$ & $29.88^{\mathrm{a}}$ & $33.02^{\mathrm{a}}$ & $27.79^{\mathrm{a}}$ \\
$\mathrm{Cu}$ & $3.63^{\mathrm{a}}$ & $3.92^{\mathrm{a}}$ & $3.32^{\mathrm{a}}$ & $3.39^{\mathrm{a}}$ \\
$\mathrm{Zn}$ & $8.29^{\mathrm{a}}$ & $8.48^{\mathrm{a}}$ & $8.07^{\mathrm{a}}$ & $8.4^{\mathrm{a}}$ \\
$\mathrm{P}$ & 0.0 & 0.0 & 0.0 & 0.0
\end{tabular}

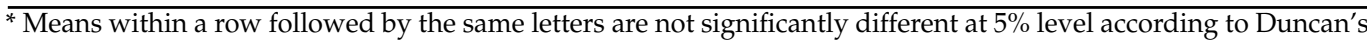
multiple range test.

\subsection{Extract Treatments' Effects on Lettuce Plants' Total and Free Amino Acid Content}

All amino acid contents except for proline were highest in Chinese chives, followed by soybean leaves and then soybean stems (Table 5). Aspartic acid, methionine, leucine, tyrosine, histidine, and lysine contents in lettuce plants increased in response to treatment with Chinese chive, while proline, alanine, valine, methionine, tyrosine, lysine, and arginine contents increased in response to soybean leaf treatment when compared with the control (Table 6). In addition, aspartic acid, proline, alanine, valine, leucine, tyrosine, lysine, and arginine in lettuce plants increased in response to treatment with soybean stems when compared with the control. Moreover, tyrosine, and lysine contents in lettuce plants were increased by treatments with all test extracts. Thus, the increase in total amino acid contents in lettuce plants in response to Chinese chive and soybean leaf and stem extracts may be related to the higher levels of these compounds in the parent materials.

Among free amino acids, aspartic acid and proline levels were highest in Chinese chives followed by soybean leaves and then soybean stems (Table 7). However, the levels of other free amino acids such as threonine and serine in Chinese chives were higher than in soybean leaves and stems. There were no differences in free amino acid contents between soybean leaves and stems. Moreover, 12, 13, and 9 of the 17 free amino acids in lettuce plants increased in response to treatment with Chinese chive and soybean leaf and stem extracts, respectively, when compared with the control (Table 8). Free amino acids showed greater increases in response to soybean leaf extracts than Chinese chive and soybean stem extracts. Similar to the total amino acids, the increase in free amino acid contents in lettuce plants in response to Chinese chive and soybean leaf and stem extracts may be related to higher levels in the parent materials. Thus, the lettuce growth induced by selected plant extracts was associated with an increase in amino acids. It is clear that foliar application of either amino acids or phenols significantly promoted the growth parameters in terms of shoot height and fresh and dry biomass of Ammi visage L. [27]. Phenols and amino acid treatments resulted in qualitative differences in the components of essential oil. In another study, seaweed and yeast extracts increased protein content in the plant Vicia faba [1]. The higher protein content could be due to the incorporation of the amino acids used directly for protein biosynthesis. 
Table 5. Total amino acid contents in Chinese chive leaf, soybean leaf, and soybean stems (unit: mg\%).

\begin{tabular}{cccc}
\hline Amino Acid & Chinese Chive & Soybean Leaf & Soybean Stem \\
\hline Aspartic acid & $1559.34^{\mathrm{a}}$ & $522.92^{\mathrm{b}}$ & $175.71^{\mathrm{c}}$ \\
Threonine & $515.41^{\mathrm{a}}$ & $173.73^{\mathrm{b}}$ & $53.44^{\mathrm{c}}$ \\
Serine & $704.56^{\mathrm{a}}$ & $282.77^{\mathrm{b}}$ & $100.25^{\mathrm{c}}$ \\
Glutamic acid & $2049.93^{\mathrm{a}}$ & $461.73^{\mathrm{b}}$ & $121.46^{\mathrm{c}}$ \\
Proline & $168.27^{\mathrm{b}}$ & $267.66^{\mathrm{a}}$ & $95.23^{\mathrm{c}}$ \\
Glycine & $669.55^{\mathrm{a}}$ & $259.85^{\mathrm{b}}$ & $64.17^{\mathrm{c}}$ \\
Alanine & $903.48^{\mathrm{a}}$ & $258.91^{\mathrm{b}}$ & $68.43^{\mathrm{c}}$ \\
Valine & $373.33^{\mathrm{a}}$ & $118.92^{\mathrm{b}}$ & $37.24^{\mathrm{c}}$ \\
Methionine & $180.22^{\mathrm{a}}$ & $48.46^{\mathrm{b}}$ & $12.14^{\mathrm{c}}$ \\
Isoleucine & $264.58^{\mathrm{a}}$ & $88.34^{\mathrm{b}}$ & $24.36^{\mathrm{c}}$ \\
Leucine & $800.00^{\mathrm{a}}$ & $283.43^{\mathrm{b}}$ & $76.00^{\mathrm{c}}$ \\
Tyrosine & $262.23^{\mathrm{a}}$ & $113.05^{\mathrm{b}}$ & $21.41^{\mathrm{c}}$ \\
Phenylalanine & $434.63^{\mathrm{a}}$ & $153.68^{\mathrm{b}}$ & $43.85^{\mathrm{c}}$ \\
Histidine & $949.93^{\mathrm{a}}$ & $378.83^{\mathrm{b}}$ & $174.22^{\mathrm{c}}$ \\
Lysine & $662.26^{\mathrm{a}}$ & $194.92^{\mathrm{b}}$ & $80.21^{\mathrm{c}}$ \\
Arginine & $507.91^{\mathrm{a}}$ & $191.91^{\mathrm{b}}$ & $34.62^{\mathrm{c}}$ \\
\hline Total & $11,005.6^{\mathrm{b}}$ & 3799.0 & $1185.7^{\mathrm{b}}$ \\
\hline
\end{tabular}

* Means within a row followed by the same letters are not significantly different at $5 \%$ level according to Duncan's multiple range test.

Table 6. Change in total amino acids of lettuce plants after treatments of selected plant extracts. Parameters were measured at 7 days treatment (unit: $\mathrm{mg} \%$ ).

\begin{tabular}{ccccc}
\hline Amino Acid & Control & Chinese Chive & Soybean Leaf & Soybean Stem \\
\hline Aspartic acid & $1670.56^{\mathrm{c} *}$ & $1773.64^{\mathrm{b}}$ & $1710.26^{\mathrm{c}}$ & $1882.23^{\mathrm{a}}$ \\
Threonine & $761.136^{\mathrm{a}}$ & $746.51^{\mathrm{a}}$ & $776.52^{\mathrm{a}}$ & $793.73^{\mathrm{a}}$ \\
Serine & $733.65^{\mathrm{a}}$ & $742.00^{\mathrm{a}}$ & $773.20^{\mathrm{a}}$ & $780.57^{\mathrm{a}}$ \\
Glutamic acid & $1966.84^{\mathrm{a}}$ & $1950.73^{\mathrm{a}}$ & $2013.24^{\mathrm{a}}$ & $2065.79^{\mathrm{a}}$ \\
Proline & $1028.43^{\mathrm{c}}$ & $1022.95^{\mathrm{c}}$ & $1123.14^{\mathrm{b}}$ & $1206.24^{\mathrm{a}}$ \\
Glycine & $1019.39^{\mathrm{a}}$ & $1042.37^{\mathrm{a}}$ & $1044.69^{\mathrm{a}}$ & $1089.29^{\mathrm{a}}$ \\
Alanine & $1130.28^{\mathrm{b}}$ & $1162.52^{\mathrm{b}}$ & $1204.42^{\mathrm{a}}$ & $1263.15^{\mathrm{a}}$ \\
Valine & $1119.38^{\mathrm{c}}$ & $1140.93^{\mathrm{c}}$ & $1195.88^{\mathrm{b}}$ & $1289.20^{\mathrm{a}}$ \\
Methionine & $109.32^{\mathrm{c}}$ & $145.09^{\mathrm{a}}$ & $131.74^{\mathrm{b}}$ & $121.49^{\mathrm{bc}}$ \\
Isoleucine & $1252.70^{\mathrm{a}}$ & $1299.32^{\mathrm{a}}$ & $1286.59^{\mathrm{a}}$ & $1208.90^{\mathrm{a}}$ \\
Leucine & $1232.15^{\mathrm{b}}$ & $1383.38^{\mathrm{a}}$ & $1239.60^{\mathrm{b}}$ & $1383.79^{\mathrm{a}}$ \\
Tyrosine & $224.61^{\mathrm{c}}$ & $257.75^{\mathrm{b}}$ & $348.049^{\mathrm{a}}$ & $259.59^{\mathrm{b}}$ \\
Phenylalanine & $726.4^{\mathrm{a}}$ & $802.86^{\mathrm{a}}$ & $772.61^{\mathrm{a}}$ & $822.11^{\mathrm{a}}$ \\
Histidine & $461.51^{\mathrm{b}}$ & $584.00^{\mathrm{a}}$ & $524.86^{\mathrm{ab}}$ & $526.39^{\mathrm{ab}}$ \\
Lysine & $694.18^{\mathrm{c}}$ & $742.25^{\mathrm{b}}$ & $814.14^{\mathrm{a}}$ & $838.41^{\mathrm{a}}$ \\
Arginine & $757.76^{\mathrm{c}}$ & $770.71^{\mathrm{bc}}$ & $817.24^{\mathrm{a}}$ & $810.23^{\mathrm{ab}}$ \\
\hline Total & $14,888.2$ & $15,567.1$ & $15,776.1$ & $16,341.1$ \\
\hline
\end{tabular}

* Means within a row followed by the same letters are not significantly different at $5 \%$ level according to Duncan's multiple range test. 
Table 7. Free amino acid contents in Chinese chive leaf, soybean leaf, and soybean stems (unit: mg\%).

\begin{tabular}{cccc}
\hline Amino Acid & Chinese Chive & Soybean Leaf & Soybean Stem \\
\hline Aspartic acid & $50.41^{\mathrm{a}}$ & $10.42^{\mathrm{b}}$ & $1.71^{\mathrm{c}}$ \\
Threonine & $46.81^{\mathrm{a}}$ & $5.02^{\mathrm{b}}$ & $0.00^{\mathrm{b}}$ \\
Serine & $197.9^{\mathrm{a}}$ & $5.91^{\mathrm{b}}$ & $5.82^{\mathrm{b}}$ \\
Glutamic acid & $132.84^{\mathrm{a}}$ & $15.73^{\mathrm{b}}$ & $4.32^{\mathrm{b}}$ \\
Proline & $11.02^{\mathrm{a}}$ & $8.02^{\mathrm{b}}$ & $1.71^{\mathrm{c}}$ \\
Glycine & $16.00^{\mathrm{a}}$ & $2.41^{\mathrm{b}}$ & $0.34^{\mathrm{b}}$ \\
Alanine & $106.74^{\mathrm{a}}$ & $8.12^{\mathrm{b}}$ & $0.82^{\mathrm{b}}$ \\
Valine & $49.00^{\mathrm{a}}$ & $5.31^{\mathrm{b}}$ & $0.53^{\mathrm{b}}$ \\
Methionine & $8.22^{\mathrm{a}}$ & $1.00^{\mathrm{b}}$ & $0.22^{\mathrm{b}}$ \\
Isoleucine & $28.33^{\mathrm{a}}$ & $3.91^{\mathrm{b}}$ & $0.32^{\mathrm{b}}$ \\
Leucine & $64.24^{\mathrm{a}}$ & $7.32^{\mathrm{b}}$ & $0.61^{\mathrm{b}}$ \\
Tyrosine & $33.38^{\mathrm{a}}$ & $1.84^{\mathrm{b}}$ & $0.21^{\mathrm{b}}$ \\
Phenylalanine & $41.25^{\mathrm{a}}$ & $4.45^{\mathrm{b}}$ & $0.62^{\mathrm{b}}$ \\
Histidine & $102.13^{\mathrm{a}}$ & $5.93^{\mathrm{b}}$ & $2.43^{\mathrm{b}}$ \\
Lysine & $53.44^{\mathrm{a}}$ & $4.71^{\mathrm{b}}$ & $0.62^{\mathrm{b}}$ \\
Arginine & $30.16^{\mathrm{a}}$ & $3.62^{\mathrm{b}}$ & $0.41^{\mathrm{b}}$ \\
\hline Total & $971.8^{\mathrm{a}}$ & 93.6 & 20.7 \\
\hline
\end{tabular}

* Means within a row followed by the same letters are not significantly different at 5\% level according to Duncan's multiple range test.

Table 8. Change in free amino acids of lettuce plants after treatments of selected plant extracts. Parameters were measured 7 days after treatment (unit: $\mathrm{mg} \%$ ).

\begin{tabular}{ccccc}
\hline Amino Acid & Control & Chinese Chive & Soybean Leaf & Soybean Stem \\
\hline Aspartic acid & $81.55^{\mathrm{c} *}$ & $118.03^{\mathrm{ab}}$ & $107.08^{\mathrm{b}}$ & $124.79^{\mathrm{a}}$ \\
Threonine & $73.75^{\mathrm{c}}$ & $85.49^{\mathrm{b}}$ & $92.64^{\mathrm{a}}$ & $73.07^{\mathrm{c}}$ \\
Serine & $279.74^{\mathrm{c}}$ & $320.3^{\mathrm{b}}$ & $473.81^{\mathrm{a}}$ & $323.63^{\mathrm{b}}$ \\
Glutamic acid & $97.27^{\mathrm{b}}$ & $117.77^{\mathrm{a}}$ & $104.92^{\mathrm{ab}}$ & $104.99^{\mathrm{ab}}$ \\
Proline & $122.93^{\mathrm{c}}$ & $157.20^{\mathrm{a}}$ & $130.68^{\mathrm{bc}}$ & $141.66^{\mathrm{b}}$ \\
Glycine & $5.20^{\mathrm{c}}$ & $5.39^{\mathrm{c}}$ & $7.47^{\mathrm{a}}$ & $6.53^{\mathrm{b}}$ \\
Alanine & $135.7^{\mathrm{c}}$ & $151.88^{\mathrm{ab}}$ & $148.77^{\mathrm{bc}}$ & $153.28^{\mathrm{a}}$ \\
Valine & $99.49^{\mathrm{c}}$ & $115.86^{\mathrm{b}}$ & $141.64^{\mathrm{a}}$ & $109.38^{\mathrm{bc}}$ \\
Methionine & $5.85^{\mathrm{c}}$ & $7.11^{\mathrm{b}}$ & $10.72^{\mathrm{a}}$ & $7.09^{\mathrm{b}}$ \\
Isoleucine & $112.82^{\mathrm{c}}$ & $125.97^{\mathrm{b}}$ & $169.88^{\mathrm{a}}$ & $110.47^{\mathrm{c}}$ \\
Leucine & $51.26^{\mathrm{c}}$ & $59.99^{\mathrm{b}}$ & $71.74^{\mathrm{a}}$ & $57.80^{\mathrm{b}}$ \\
Tyrosine & $44.28^{\mathrm{d}}$ & $76.21^{\mathrm{a}}$ & $64.65^{\mathrm{b}}$ & $51.83^{\mathrm{c}}$ \\
Phenylalanine & $62.11^{\mathrm{b}}$ & $63.61^{\mathrm{b}}$ & $104.80^{\mathrm{a}}$ & $63.61^{\mathrm{b}}$ \\
Histidine & $46.75^{\mathrm{b}}$ & $48.02^{\mathrm{b}}$ & $65.81^{\mathrm{a}}$ & $42.62^{\mathrm{c}}$ \\
Lysine & $41.28^{\mathrm{b}}$ & $44.5^{\mathrm{b}}$ & $51.74^{\mathrm{a}}$ & $41.82^{\mathrm{b}}$ \\
Arginine & $34.06^{\mathrm{d}}$ & $38.40^{\mathrm{c}}$ & $47.94^{\mathrm{b}}$ & $55.57^{\mathrm{a}}$ \\
\hline Total & 1302.6 & 1545.0 & 1809.3 & 1476.6
\end{tabular}

${ }^{*}$ Means within a row followed by the same letters are not significantly different at $5 \%$ level according to Duncan's multiple range test.

\subsection{Extract Treatments' Effects on Lettuce Plants' Free Sugar Content}

Fructose and glucose were detected in Chinese chive in the highest amount, followed by soybean leaf and, in the lowest amount, soybean stem (Table 9). Additionally, fructose content in lettuce plants decreased following treatment with Chinese chive and soybean stem extracts (Table 10), whereas glucose and maltose contents increased in response to treatment with Chinese chive and soybean leaf extracts. In a similar study, enhanced accumulation of both total protein and total sugars in rock plants observed in response to treatments with Moringa leaf and twig extracts were caused by the high protein, sugar, and starch content of the entire M. oleifera plant [2]. In the present study, the increase in glucose and maltose contents in lettuce plants in response to treatments with Chinese 
chive and soybean leaf extracts may have been due to the high free sugar contents of Chinese chive and soybean leaves. Taken together, these results present strong evidence of the improvement of quality of lettuce plants in response to treatment with the selected plant extracts.

Table 9. Free sugar contents in Chinese chive leaf, soybean leaf, and soybean stems (unit: \%).

\begin{tabular}{cccc}
\hline & Chinese Chive & Soybean Leaf & Soybean Stem \\
\hline Fructose & $1.28^{\mathrm{a} *}$ & $0.46^{\mathrm{b}}$ & $0.19^{\mathrm{c}}$ \\
Glucose & $1.88^{\mathrm{a}}$ & $0.07^{\mathrm{b}}$ & $0.00^{\mathrm{c}}$ \\
\hline Total & 3.16 & 0.53 & 0.19 \\
\hline
\end{tabular}

* Means within a row followed by the same letters are not significantly different at 5\% level according to Duncan's multiple range test.

Table 10. Change in free sugar contents of lettuce plants after treatments of selected plant extracts. Parameters were measured 7 days after treatment (unit: \%).

\begin{tabular}{ccccc}
\hline & Control & Chinese Chive & Soybean Leaf & Soybean Stem \\
\hline Fructose & $1.99^{\mathrm{a}}$ & $1.61^{\mathrm{c}}$ & $2.00^{\mathrm{a}}$ & $1.83^{\mathrm{b}}$ \\
Glucose & $2.31^{\mathrm{b}}$ & $2.42^{\mathrm{a}}$ & $2.49^{\mathrm{a}}$ & $2.22^{\mathrm{b}}$ \\
Maltose & $0.30^{\mathrm{c}}$ & $0.32^{\mathrm{b}}$ & $0.36^{\mathrm{a}}$ & $0.30^{\mathrm{c}}$ \\
\hline Total & 4.60 & 4.35 & 4.85 & 4.35
\end{tabular}

* Means within a row followed by the same letters are not significantly different at 5\% level according to Duncan's multiple range test.

\section{Conclusions}

Based on our studies, it is evident that a lettuce plant's mineral, amino acid, and free sugar contents can be increased through plant extract applications. The effects of these extract applications, however, were not always as expected. In studies using an extract with a high level of a particular mineral, for example, the treated lettuce plants did not necessarily experience a corresponding increase in that mineral. By contrast, some extract applications were especially useful in increasing the mineral, amino acid, or free sugar contents in the treated lettuce plant. Most notably, total and free amino acid levels were higher in treated lettuce plants regardless of which extract was used. The fact that glucose and maltose contents in lettuce plants were higher after treatments of Chinese chive and soybean leaf extracts is also of interest. Considering both of these findings, we believe that our study provides further evidence that aspects of a plant's nutritional value can be improved through the use of plant extract applications.

Author Contributions: Data curation, S.J.J; writing-review and editing, Y.I.K. All authors have read and agreed to the published version of the manuscript.

Funding: This work was carried out with the support of the "Cooperative Research Program for Agriculture Science \& Technology Development (Project No. PJ01083903)" Rural Development Administration, Republic of Korea.

Institutional Review Board Statement: Not applicable.

Informed Consent Statement: Not applicable.

Acknowledgments: The authors acknowledge the help of Min Hee Park, Hyo Jin Lee, and Ok Gi Lee in crop cultivation.

Conflicts of Interest: The authors declare no conflict of interest. 


\section{References}

1. Abbas, S.M. The influence of biostimulants on the growth and on the biological composition of Vicia faba cv. Giza 3 beans. Rom. Biotechnol. Lett. 2013, 18, 8061-8068.

2. Abdalla, M.M. The potential of Moringa oleifera extracts as a biostimulant in enhancing the growth, biochemical and hormonal contents in rocket (Eruca vesicaria subsp. sativa) plants. J. Plant Biochem. Physiol. 2013, 5, 42-49.

3. Kunicki, E.; Grabowska, A.; Sekara, A.; Wojciechowska, R. The effect of cultivar type, time of cultivation, and biostimulant treatment on the yield of spinach (Spinacia oleracea L.). Folia Horticult. 2010, 22, 9-13. [CrossRef]

4. Chae, J.C.; Gang, B.H.; Park, S.J.; Kim, S.H. Samgo Cultivation Principles; Hyangmunsa: Seoul, South Korea, 2008; p. 434. (In Korean)

5. Newell-Mcgloughlin, M. Nutritionally improved agricultural crops. Plant Physiol. 2008, 147, 939-953. [CrossRef] [PubMed]

6. Newell-Mcgloughlin, M. Modifying agricultural crops for improved nutrition. New Biotechnol. 2010, 27, 494-504. [CrossRef] [PubMed]

7. Holm, P.B.; Kristiansen, K.N.; Pedersen, H.B. Transgenic approaches in commonly consumed cereals to improve iron and zinc content and bioavailability. J. Nutr. 2002, 132, 514S-516S. [CrossRef] [PubMed]

8. White, P.J.; Broadley, M.R. Biofortification of crops with seven mineral elements often lacking in human diets-iron, zinc, copper calcium, magnesium, selenium and iodine. New Phytol. 2009, 182, 49-84. [CrossRef] [PubMed]

9. FAO (Food and Agriculture Organization of the United Nations). 2006. Available online: http:// faostat.fao.org/ (accessed on 9 September 2015).

10. KREI (Korea Rural Economic Institute). 2017. Available online: http://www.krei.re.kr/web/www/home/ (accessed on 11 December 2017).

11. Yuji, Y.; Yoshitaka, M.; Yoshinori, S.; Kazunori, O.; Tatsuo, T.; Eiichi, M.; Kei, H.; Yasushi, U. Characterization of volatile sulphurcontaining compounds generated in crushed leaves of Chinese chive (Allium tuberosum Rottler). Food Chem. 2010, 120, 343-348.

12. Moon, G.S.; Ryu, B.M.; Lee, M.J. Components and antioxidant activities of Buchu (Chinese chives) harvested at different times. Korean J. Food Sci. Technol. 2003, 35, 493-498.

13. Lee, J.G.; Lee, B.Y.; Lee, H.J. Accumulation of phytotoxic organic acids in reused nutrient solution during hydroponic cultivation of lettuce (Lactuca sativa L.). Sci. Hortic. 2006, 110, 119-128. [CrossRef]

14. Park, K.W.; Lee, J.M. Wrap-ups: A unique method of vegetable usage and consumption in Korea. Chron. Horticult. 2006, 46, 13-15.

15. Jang, S.J. Control of Diseases, Insects, and Weeds and Growth Promotion of Crops by Useful Plant Extracts. Ph.D. Thesis, Sunchon National University, Suncheon, South Korea, 2017; p. 205.

16. Zodape, S.; Mukherjee, S.; Reddy, M.; Chaudhary, D. Effect of Kappaphycus alvarezii (Doty) Doty ex silva. extract on grain quality, yield and some yield components of wheat (Triticum aestivum L.). Int. J. Plant Prod. 2009, 3, 97-101.

17. Woo, S.J.; Ryoo, S.S. Preparation methods for atomic absorption and spectrophotometry of food samples. Korean J. Food Sci. Technol. 1983, 15, 225-230.

18. Ohara, I.; Shujiro, A. Comparison of protein precipitants for the determination of free amino acids in plasma. Agric. Biol. Chem. 1979, 43, 1473-1478.

19. Wilson, A.M.; Work, T.M.; Bushway, A.A.; Bushway, R.J. HPLC determination of fructose, glucose, and sucrose in potatoes. J. Food Sci. 1981, 46, 300-301. [CrossRef]

20. SAS (Statistical Analysis System). SAS/STAT User's Guide, 7th ed.; Electronic Version; Statistical Analysis System Institute: Cary, NC, USA, 2000.

21. Ryu, S.H.; Lee, H.S.; Lee, Y.S.; Moon, G.S. Contents of isoflavones and antioxidative related compounds in soybean leaf, soybean leaf jangachi, and soybean leaf kimchi. Korean J. Food Cook Sci. 2005, 21, 433-439.

22. Porter, P.M.; Banwart, W.L.; Hassett, J.J. Phenolic acids and flavonoids in soybean root and leaf extracts. Environ. Exper. Bot. 1986, 26, 65-73. [CrossRef]

23. Stutte, C.A.; Park, H. Effects of Nitrogen source on PRE-point and free amino acids in soybean leaves different in phosphorus sensitivity. Korean J. Soil Sci. Fertil. 1973, 6, 239-244.

24. Fan, D.; Hodges, D.M.; Zhang, J.; Kirby, C.W.; Ji, X.; Locke, S.J.; Critchley, A.T.; Prithiviraj, B. Commercial extract of the brown seaweed Ascophyllum nodosum enhances phenolic antioxidant content of spinach (Spinacia oleracea L.) which protects Caenorhabditis elegans against oxidative and thermal stress. Food Chem. 2011, 124, 195-202. [CrossRef]

25. Badry, B.; Salim, M. Influence of biochar and seaweed extract applications on growth, yield and mineral composition of wheat (Triticum aestivum L.) under sandy soil conditions. Ann. Agric. Sci. 2016, 61, 257-265.

26. Mancuso, S.; Azzarello, E.; Mugnai, S.; Briand, X. Marine bioactive substance (IPA extract) improve foliar ion uptake and water stress tolerance in potted Vitis vinifera plants. Adv. Hortic. Sc. 2006, 20, 156-161.

27. Talaat, I.M.; Khattab, H.I.; Ahmed, A.M. Changes in growth, hormones levels and essential oil content of Ammi visnaga L. plants treated with some bioregulators. Saudi J. Biol. Sci. 2014, 21, 355-365. [CrossRef] [PubMed] 